\title{
Pengaruh Pendapatan, Jumlah Nasabah Dan Tingkat Suku Bunga Terhadap Penyaluran Kredit Pt Pegadaian Cabang Kabupaten Jember Periode 2013 -2017
}

\author{
Ratih Rachmawati \\ Sekolah Tinggi Ilmu Ekonomi Mandala, Jember
}

\begin{abstract}
The research objective was to analyze the large number, number of customers, and interest rates on the loan distribution of PT Pegadaian Branch of Jember Regency.The type of data used in this study is secondary data consisting of time series data on income, number of customers obtained through the pawnshop office which is the object of research and interest rates for the period 2013-2017 obtained from BI which is the object of the research. The data is processed using computer software "SPSS 22" with multiple regression analysis methods. The Pawnshop Branch of Kabupaten Jember is very positive and significant towards lending to PT Pegadaian Branch of Kabupaten Jember, while the Interest Rate does not significantly influence the lending of PT Pegadaian Branch of Kabupaten Jember. Together, it focuses positively and significantly on the loan distribution of PT Pegadaian Branch of Jember Regency
\end{abstract}

Keywords: Income, Number of customers, Interest rates, Credit Distribution

\section{Pendahuluan}

Dalam kehidupan sehari-hari, kita sering dihadapkan pada kebutuhan tertentu, di mana dengan berjalannya waktu, maka banyak kebutuhan yang harus dipenuhi. Sedangkan kita ketahui bahwa alat untuk memenuhi kebutuhan tersebut bersifat terbatas,sehingga dalam upaya untuk memenuhi kebutuhan tersebut dibutuhkan dana. Dana ini dapat berasal dari kekayaan sendiri, maupun dari pinjaman yang bersumber dari bank dan non bank. Bagi sebagian masyarakat yang memiliki kelebihan dana, maka biasanya dana tersebut disimpan dalam bentuk investasi berupa tanah, emas, surat-surat berharga, dan deposito atau dipinjamkan kepada pihak lain dengan mendapatkan imbalan atau keuntungan dari dana yang dipinjamkan tersebut. Sedangkan bagi sebagian orang lainnya yang kekurangan dana, maka dapat memperoleh dana dengan cara meminjam kepada pihak lain yang kelebihan dana atau meminjam ke lembaga lainnya, baik itu berupa uang tunai 
ataupun dalam bentuk lainnya yang segera diuangkan untuk dapat memenuhi kekurangan dana tersebut. Bagi golongan masyarakat yang kekurangan dana, sangatlah penting baginya arti dari suatu lembaga keuangan yang dapat memenuhi kebutuhan mereka. PT Pegadaian Jember sebagai lembaga perkreditan yang memiliki tujuan khusus yaitu menyalurkan uang pinjaman atas dasar hukum gadai yang ditujukan untuk mencegah praktek ijon, pegadaian gelap, riba, serta pinjaman tidak wajar lainnya. Perusahaan ini meningkatkan peranannya dalam menyalurkan pinjaman bagi masyarakat. Adapun nasabah PT Pegadaian terdiri dari masyarakat golongan ekonomi lemah yang kurang mendapat pelayanan dari lembaga keuangan atau perbankan, sehingga masyarakat menengah ke bawah memerlukan pinjaman secara mudah dan cepat. Berpijak dari kenyataan tersebut di atas, PT Pegadaian merupakan salah satu alternatif bagi masyarakat untuk mendapatkan kredit, baik skala kecil maupun skala besar, dengan pelayanan yang mudah, cepat dan aman. Dalam kenyataannya menunjukkan bahwa sistem pelayanan yang mudah, cepat dan aman memang sangat dibutuhkan oleh masyarakat, khususnya masyarakat ekonomi lemah. Kemudahan dan kesederhanaan dalam prosedur perolehan kredit merupakan modal dasar dalam mendekati pangsa pasar pegadaian. Hal ini terbukti dengan meningkatnya kredit yang disalurkan oleh PT Pegadaian Cabang Kabupaten Jember Semakin banyak kredit yang disalurkan,ini berarti kinerja pegadaian semakin optimal.

Tabel 1.4. Perkembangan penyaluran kredit, jumlah nasabah Pendapatan pada PT Pegadaian dan Tingkat Suku Bunga tahun 20013-2017

\begin{tabular}{ccccc}
\multicolumn{7}{c}{ (dalam jutaan Rupiah ) } & \\
\hline Tahun & Jumlah nasabah & Pendapatan Pegadaian & $\begin{array}{c}\text { Tingkat suku } \\
\text { bunga }\end{array}$ & $\begin{array}{c}\text { Kredit yang } \\
\text { disalurkan }\end{array}$ \\
\hline 2013 & 2292318 & 15949598484 & 51,34 & 12274466040 \\
2014 & 2635873 & 17293295656 & 83,59 & 12087689424 \\
2015 & 577274 & 18027276352 & 77,50 & 11857112172 \\
2016 & 823980 & 18880983168 & 77,26 & 11815997088 \\
2017 & 854182 & 19624963872 & 42,09 & 12008816184 \\
\hline
\end{tabular}

Sumber: Data Diolah, 2017

Dengan melihat jumlah pinjaman kredit yang disalurkan, jumlah nasabah mulai dari tahun 2013 s.d tahun 2017 yang semakin turun, Pendapatan pegadaian dari tahun 2013 s.d tahun 2017 meningkat dari tahun 2013 jumlahnya sebesar Rp 15.949.598.484 dan tahun 2017 jumlah sebesar Rp 19.624.963.876,- tingkat suku 
bunga yang berfluktuatif maka penulis tertarik untuk meneliti “ Pengaruh Pendapatan, Jumlah Nasabah, dan tingkat suku bunga terhadap Penyaluran Kredit di PT Pegadaian Cabang Jember.

Berdasarkan latar belakang masalah yang telah dikemukakan di atas, penulis membatasi penelitian ini pada masalah-masalah penyaluran kredit PT Pegadaian Cabang Jember periode 2013-2017. Untuk itu permasalahan yang akan dibahas dapat dirumuskan yaitu 1. Bagaimana pengaruh pendapatan perum pegadaian terhadap penyaluran kredit perum pegadaian di kabupaten Jember?, 2. Bagaimana pengaruh jumlah nasabah terhadap penyaluran kredit Perum Pegadaian di Kabupaten Jember, 3. Bagaimana pengaruh tingkat suku bunga terhadap penyaluran kredit Perum Pegadaian di Kabupaten Jember?.

\section{Tinjauan Pustaka}

Pegadaian adalah perusahaan milik Pemerintah yang bertugas menyalurkan pinjaman atau kredit dengan jaminan benda bergerak. Kata kredit bukan hal yang asing dalam masyarakat, tetapi merupakan istilah yang sangat populer, baik dikalangan masyarakat perkotaan maupun pedesaan. Terjadinya hubungan perkreditan pada hakekatnya timbul sejak manusia tidak dapat memenuhi semua kebutuhanya dan tidak dapat secara langsung menukar barang atau jasa yang dibutuhkannya dengan barang, jasa atau alat penukar yang dimilikinya.

Sigit Triandaru \& Totok (2006), PT Pegadaian adalah satu-satunya badan usaha di Indonesia yang secara resmi mempunyai izin untuk melaksanakan kegiatan lembaga keuangan berupa pembiayaan dalam bentuk penyaluran dana ke masyarakat atas dasar hukum gadai. Kepercayaan yang ditanamkan masyarakat dalam dirinya terhadap prosedur yang diterimanya dari pegadaian dapat mempererat hubungan masyarakat untuk mengambil pinjaman dana (kredit) pada PT Pegadaian. Adapun barang-barang yang dijadikan jaminan dapat berupa emas, perhiasan, elektonik rumah tangga, kamera, alat musik dan lain sebagainya sesuai dengan yang disepakati oleh pegadaian.

Prosedur memperoleh uang pinjaman dari Pegadaian bagi masyarakat yang membutuhkan dana segera sangat sederhana, mudah, dan cepat. Berikut ini merupakan mekanisme jasa pembiayaan yang dilakukan oleh pegadaian menurut 


\section{Pengertian Kredit}

Dewasa ini kredit merupakan perkataan yang tidak asing lagi bagi masyarakat kita, tidak saja dikenal oleh masyarakat perkotaan tetapi juga masyarakat desa. Kata kredit tersebut sudah sangat populer dikalangan masyarakat disebabkan karena manusia adalah Homo Economicus dan setiap manusia selalu berusaha untuk memenuhi kebutuhan hidup. Kebutuhan manusia beraneka ragam sesuai dengan harkatnya selalu meningkat, sedangkan kemampuan untuk mencapai sesuatu yang diinginkannya terbatas. Hal ini menyebabkan manusia memerlukan bantuan untuk memenuhi hasrat dan cita-citanya. Dalam hal ini ia berusaha, maka untuk meningkatkan usahanya untuk meningkatkan daya guna suatu barang, ia memerlukan bantuan dalam bentuk permodalan. Bantuan dari bank maupun lembaga keuangan bukan bank dalam bentuk tambahan modal inilah yang sering disebut dengan kredit(Thomas Suyatno dkk, 2003 : 13 ). Istilah kredit berasal dari bahasa Yunani credere yang berarti kepercayaan/ truth atau faith (Thomas Suyatno dkk, 2003, 11 ). Oleh karena itu dasar kredit adalah kepercayaan seseorang atau badan yang memberikan kredit bahwa penerima kredit pada masa yang akan datang sanggup memenuhi segala sesuatu yang telah dijanjikan. Apa yang dijanjikan itu dapat berupa barang/uang atau jasa. Kredit dalam arti ekonomi adalah penundaan pembayaran dari prestasi yang diberikan sekarang baik dalam bentuk uang, barang atau jasa. Dengan demikian kredit dapat pula berarti bahwa pihak pertama memberikan sesuatu baik itu barang uang atau jasa kepada pihak lain, sedangkan pengembaliaannya akan diterima kemudian dalam jangka waktu tertentu.

Pengertian kredit menurut Undang-undang Perbankan No. 10 Tahun 1998 Bab I Pasal 17 ayat 11, adalah penyediaan uang atau tagihan yang dapat dipersamakan dengan itu, berdasarkan persetujuan atau kesepakatan pinjam meminjam antara bank maupun lembaga keuangan bukan bank dengan pihak lain yang mewajibkan pihak peminjam untuk melunasi hutangnya setelah jangka waktu tertentu dengan pemberian bunga, imbalan atau pembagian hasil keuntungan.

\section{Analisis Dalam Pemberian Kredit}

Sebagaimana kita ketahui bahwa dalam setiap pemberian kredit diperlukan adanya pertimbangan dan kehati-hatian agar kepercayaan yang merupakan unsur utama 
dalam kredit benar-benar terwujud sehingga kredit yang diberikan dapat mengenai sasarannya dan terjaminnya pengembalian kredit tersebut tepat pada waktunya sesuai denga perjanjian. Banyak konsep yang dikemukakan oleh berbagai pihak dalam rangka upaya merumuskan persyaratan atau azas-azas yang sehat dalam suatu pemberian kredit. Di bawah ini akan dijelaskan 3 macam konsep tentang prinsip-prinsip/syarat-syarat/azas-azas pemberian kredit secara sehat sebagai berikut:

\section{Prinsip-prinsip 5 C}

a. Character yaitu :"character" atau watak dari para calon peminjam merupakan salah satu pertimbangan yang terpenting dalam memutuskan pemberian kredit. Bank sebagai pemberi kredit harus yakin bahwa calon peminjam termasuk orang yang bertingkah laku baik.

b. Capacity Yaitu :Pihak bank harus tahu dengan pasti sampai dimana kemampuan manjalankan menjalankan usaha calon peminjam. Kemampuan ini sangat penting mengingat bahwa kemampuan inilah yang menentukan besar kecilnya pendapatan atau penghasilan suatu perusahaan dimasa yang akan datang.

c. Capital Yaitu :Azas ini menyangkut berapa banyak dan bagaimana struktur modal yang telah dimiliki oleh calon peminjam. Yang dimaksud dengan struktur modal disini adalah ke"likuid"an modal yang telah ada, misalnya apakah seluruhnya dalam bentuk uang tunai dan harta lain yang mudah diuangkan (dicairkan) atau sebagian dalam bentuk benda-benda yang sukar diuangkan. Biasanya jika modal sendiri cukup besar, perusahaan tersebut akan kuat dalam menghadapi persaingan.

d. Condition of economy yaitu :Kondisi dan situasi ekonomi perlu juga diperhatikan dalam pertimbangan pemberian kredit, terutama dalam hubungannya dengan sektor usaha calon peminjam. Sebagai contoh adakah peraturan pemerintah yang menghambat atau mendukung pemasaran produknya, misal larangan atau dorongan ekspor. 
e. Collateral Yaitu : jaminan atau agunan yaitu harta benda milik debitur atau pihak ketiga yang diikat sebagai agunan andaikata terjadi ketidak mampuan debitur tersebut untuk menyelesaikan utangnya sesuai dengan perjanjian kredit.

\section{Alokasi Dana}

Pengertian kredit adalah suatu pemberian prestasi oleh suatu pihak kepada pihak lain, dan prestasi itu akan dikembalikan lagi pada masa tertentu yang akan datang disertai dengan suatu kontra prestasi yang berupa bunga. Pegadaian sebagai salah satu lembaga keuangan bukan bank yang bergerak dalam bidang perkreditan di Indonesia, bertugas memberikan pinjaman uang kepada masyarakat dengan hukum gadai. Gadai menurut KUH-Perdata pasal 1150, adalah suatu hak yang diperoleh seseorang berpiutang atas suatu barang bergerak yang diserahkan kepadanya oleh seseorang berhutang atau oleh seorang lain atas namanya dan yan memberikan kekuasaan kepada siberpiutang itu untuk mengambil pelunasan dari barang tersebut secara didahulukan dari pada orang-orang berpiutang lainnya; dengan kekecualian biaya untuk melelang barang tersebut dan biaya yang telah dikeluarkan untuk menyelamatkanya setelah barang itu digadaikan, biaya-biaya mana harus didahulukan.

\section{Uang Pinjaman (Jumlah kredit yang disalurkan)}

Uang pinjaman adalah besarnya uang yang diberikan kepada nasabah yang ditentukan berdasarkan taksiran dan ketentuan yang berlaku. Berdasarkan besar kecilnya uang pinjaman ini dapat dipergunakan untuk pembagia golongan barang jaminan. Untuk keabsahan pemberian uang pinjaman, penaksir atau ketua pemutus kredit membubuhkan tanda tangan dan cap keabsahan pada kolom tanda tangan Surat Bukti Kredit (SBK). Kasir pelunasan membubuhkan tanda tangan dan cap kitir bukti pembayaran.

\section{Variabel Yang Mempengaruhi Penyaluran Kredit PT Pegadaian}

\section{Pendapatan PT Pegadaian}

Tujuan didirikannya PT Pegadaian adalah mencari laba, laba ini diperoleh bila perusahaan menjalankan aktivitasnya. Aktivitas perusahaan dapat berupa penjualan jasa, penyaluran kredit, pelelangan yang akhirnya akan dijual kepada masyarakat untuk memperoleh pendapatan PT Pegadaian. PT Pegadaian, selain melayani 
kepentingan umum, juga bertujuan untuk mendapatkan laba. Pendapatan pegadaian berasal dari bunga pelunasan, bunga yang dilelang, uang kelebihan kadaluwarsa, jasa taksiran, jasa titipan dan lain-lain, sedangkan untuk bunga pelunasan, bunga yang dilelang, uang kelebihan kadaluwarsa, beda lebih kas dan lain-lain, Jumlah kesemuanya itu setelah digunakan untuk pengeluaran rutin dari kantor cabang PT Pegadaian yang bersangkutan, sisanya diserahkan kepada kas negara melalui kantor daerah setempat.

\section{Jumlah Nasabah.}

Jumlah nasabah adalah banyaknya pihak yang menggunkan jasa PT Pegadaian untuk memperoleh kredit. Berbagai lapisan masyarakat dapat memanfaatkan jasa pegadaian. Namun, sejalan dengan misinya, prioritas di berikan kepada masyarakat ekonomi lemah baik yang berpenghasilan tetap maupun yang tidak tetap. Kredit pegadaian bersifat multipropose baik untuk kebutuhan produktif, semi produktif maupun konsumtif. Berdasarkan profesi, nasabah pegadaian mayoritas dari petani (52\%) kemudian pedagang (16\%), nelayan $6 \%$, industri rumah tangga/kecil 2\% dan lain-lain $24 \%$. Jumlah nasabah pada tahun 2001 sebanyak 186 juta nasabah, 2002 sebanyak 238 juta nasabah, 2003 sebanyak 274 juta nasabh, 2004 sebanyak 323 juta nasabah dan tahun 2005 sebanyak 408 juta nasabah. Dengan banyaknya masyarakat yang meminta kredit di PT Pegadaian, ini berarti semakin besar pula kredit yang di salurkan oleh perum pegadaian.

\section{Tingkat Suku Bunga}

Menurut Lipsey (1995), suku bunga merupakan harga yang harus dibayaruntuk meminjam uang selama periode waktu tertentu dan dinyatakan dalam persentase. Berdasarkan pendapat Boediono (1998) bunga adalah harga dari dana yang disalurkan dalam bentuk pinjaman, dimana penawaran pinjaman dibentuk oleh kelompok penyimpan yaitu mereka yang memiliki pendapatan lebih besar dibandingkan kebutuhan konsumsinya selama periode tertentu sedangkan permintaan pinjaman dibentuk oleh kelompok investor.

Dwi Suryanti (2006) seperti di kutip Amen wahyudi bertujuan untuk mengetahui tingkat perkembangan besarnya nilai kredit Perum Pegadaian cabang Bantul Yogyakarta. Dalam penelitian ini menggunakan variabel dependen yaitu besarnya 
nilai kredit yang diberikan kepada masyarakat, terhadap faktor-faktor modal pegadaian, pendapatan operasional, dan jumlah agunan atau taksiran kepada masyarakat Perum Pegadaian sebagai variabel independen. Penelitian ini menggunakan alat analisis regresi berganda. Hasil penelitian menunjukkan bahwa faktor-faktor modal, pendapatan operasional, dan jumlah agunan atau taksiran Perum Pegadaian secara bersama- sama berpengaruh signifikan terhadap besarnya nilai kredit yang diberikan kepada masyarakat. Dari uji individu didapatkan hasil faktor-faktor modal, pendapatan operasional berpengaruh secara positif signikan terhadap besarnya nilai kredit yang diberikan kepada masyarakat, dan jumlah agunan atau taksiran berpengaruh secara positif tidak signifikan terhadap besarnya nilai kredit yang diberikan kepada masyarakat. Untuk asumsi klasik tidak terdapat autokorelasi, heteroskedastisitas dan multikolinieritas.

Arina Krisnawati (2011) Penelitian ini bertujuan untuk mengetahui apakah factor tingkat Dana Pihak Ketiga, Produk Domestik Bruto, Suku Bunga Kredit dan Inflasi berpengaruh terhadap penyaluran kredit pada bank umum di Indonesia. Data yang digunakan adalah data sekunder yang meliputi penyaluran kredit, DPK, PDB, Suku Bunga Kredit, Inflasi yaitu pada tahu 1995 sampai dengan 2009 yang di peroleh dari Bank Indonesia cabang Surabaya, Kantor Badan pusat Statistik Surabaya.Model analisis yang digunakn adalah model regresi linier berganda dan selanjutnya dilakukan uji hipotesis, untuk menguji pengaruh secara simultan digunakan uji-F dan secara parsial dengan uji-t. Hasil penelitian menunjukkan bahwa secara simultan Dana Pihak Ketiga,Produk Domestik Bruto , Tingkat Suku Bunga dan Inflasi terhadap variable terikatnya Penyaluran Kredit berpengaruh secara parsial dengan DPK dan Suku Bungan Kredit berpengaruh nyata terhadap penyaluran kredit, sedangkan PDB dan Inflasi tidak berpengaruh secara tidak nyata dan yang paling dominan adalah DPK.

Revol Rachmad (2007) Penelitian ini untuk mengetahui pengaruh variabel bebas $\mathrm{X} .1$ = bunga kredit bri unit, $\mathrm{X} .2$ = bunga kredit bank pesaing, $\mathrm{X} .3=$ jaminan, $\mathrm{X} .4=$ jumlah debitur dominan terhadap variabel tergantung $\mathrm{Y}=$ Jumlah kredit dengan data internal sejak Januari 2001 sampai dengan Desember 2005 . Analisis data menggunakan regresi berganda dan korelasi dengan uji t statistik dan uji F-statistik. 


\section{Hipótesa}

Berdasarkan rumusan masalah di bab 1 dan data empiris serta dukungan penelitian terdahulu maka rumusan hipotesa ini adalah:

1. Di duga bahwa ada pengaruh signifikan antara penyaluran kredit terhadap pendapatan di PT Pegadaian Cabang Kabupaten Jember

2. Di duga bahwa ada pengaruh signifikan antara Penyaluran kredit jumlah nasabah di PT Pegadaian Cabang Kabupaten Jember

3. Di duga bahwa ada pengaruh signifikan antara Penyaluran kredit terhadap tingkat suku bunga

\section{Metode Penelitian}

\section{Lokasi Penelitian}

untuk memperoleh datayang di butuhkan dalam penulisan ini, penulis melekukan penelitian pada PT Pegadaian Cabang Kabupaten Jember. Di mana, bidang usahanya bergerak di bidang jasa keuangan yang berlokasi di Kabupaten Jember

\section{Jenis Data}

a) Data kuantitatif, yaitu data numeric yang dapat memberikan penafsiran yang kokoh atau dengan kata lain data ini berupa angka-angka yang di peroleh dari laporan keuangan PT Pegadaian Cabang Kabupaten Jember

b) Data kualitatif, yaitu data yang di peroleh dalam bentuk informasi, baik secara lisan maupun tulisan dan dapat digunakan untuk mendukung data lainnya.

\section{Metode Pengumpulan Data}

Penelitian kepustakaan, yaitu metode pengumpulan data dengan cara melakukan peninjauan pustaka dari berbagai literatur, karya ilmiah, buku-buku yang menyangkut teori-teori yang relevan dengan masalah yang akan dibahas.

Penelitian lapangan, yaitu metode pengumpulan data yang dilakukan di lokasi (objek penelitian) secara langsung.

\section{Definisi Operasional Variabel}

Untuk memberikan kesamaan persepsi dalam penelitian, maka peneliti memberikan batasan definisi terhadap veriabel-veriabel yang di gunakan dalam penelitian ini, antara lain: 
1) Jumlah nasabah (X1) adalah anggota masyarakat yang sudah menjadikan PT Pegadaian sebagai alternatif dalam mendapatkan kredit.

2) Pendapatan PT Pegadaian (X2) adalah besarnya Pendapatan PT Pegadaian berdasarkan penyaluran kredit PT Pegadaian Cabang Kabupaten Jember yang diperoleh dari jasa gadai, pelelangan barang, jasa penitipan barang dan lain lain.

3) Tingkat suku bunga (X3) adalah bunga bank umum yang diberikan pada para peminjam atau harga yang harus di bayar oleh nasabah peminjam kepada bank umum

4) Penyaluran kredit PT Pegadaian (Y) adalah jumlah seluruh pinjaman atau kredit yang di berikan oleh PT Pegadaian kepada nasabah.

\section{Metode Analisis Data}

\section{Metode Regresi linier berganda}

Penelitian ini bertujuan melihat pengaruh antara variabel Pendapatan, Jumlah Nasabah, dan Inflasi terhadap Penyaluran Kredit dengan menggunakan analisis regresi linear berganda. Statistik untuk menguji hipotesis dalam penelitian ini menggunakan metode regresi linier berganda dengan rumus:

$$
Y=a+b_{1} x_{1}+b_{2} x_{2}+b_{3} x_{3}+e,
$$

Dalam hal ini,

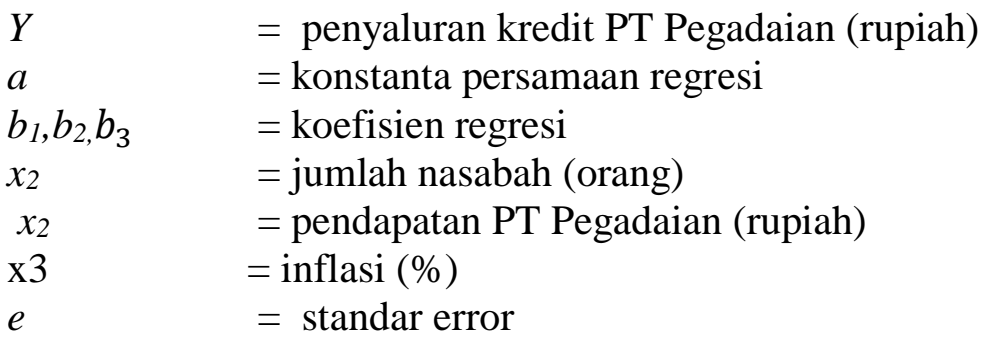

Pengujian analisis regresi meliputi uji diagnostik yaitu uji t-statistik, uji f-statistik, uji koefisisen determinasi $\left(\mathrm{R}^{2}\right)$, dan uji asumsi klasik yaitu uji autokorelasi, uji multikolinieritas dan uji heteroskedastisitas. Dalam penelitian ini semua nilai di konversi ke dalam bentuk \%.

\section{Hasil Dan Pembahasan}

\section{Analisis Regresi Linier berganda}

Regresi pengelolaan linear berganda adalah metode statistika yang digunakan untuk 
membentuk hubungan antara variabel terikat dengan variabel bebas. Apabila variabel bebas berjumlah lebih dari satu maka analisis regresi menggunakan linear berganda yang digunakan.

Persamaan regresi linear berganda adalah sebagai berikut :

$$
\mathrm{Y}=\mathrm{a}+\mathrm{b} 1 \mathrm{X} 1+\mathrm{b} 2 \mathrm{X} 2+\mathrm{b} 3 \mathrm{X} 3+\mathrm{e},
$$

\section{Dimana :}

$$
\begin{array}{ll}
\mathrm{Y} & =\text { Penyaluran Kredit } \\
\mathrm{a} & =\text { Konstanta } \\
\mathrm{X} 1 & =\text { Jumlah Nasabah } \\
\mathrm{X} 2 & =\text { Pendapatan Pegadaian } \\
\mathrm{X} 3 & =\text { Tingkat Suku Bunga } \\
\mathrm{b} 1, \mathrm{~b} 2, \mathrm{~b} 3 & =\text { koefesien } \\
\mathrm{e} & =\text { error/ Variabel Pengganggu }
\end{array}
$$

\begin{tabular}{|c|c|c|c|c|c|}
\hline \multicolumn{6}{|c|}{ Coefficients $^{\mathrm{a}}$} \\
\hline \multirow[b]{2}{*}{ Model } & \multicolumn{2}{|c|}{ Unstandardized Coefficients } & $\begin{array}{l}\text { Standardized } \\
\text { Coefficients }\end{array}$ & \multirow[b]{2}{*}{$\mathrm{t}$} & \multirow[b]{2}{*}{ Sig. } \\
\hline & $\mathrm{B}$ & Std. Error & Beta & & \\
\hline $1 \quad$ (Constant) & 4538126865,365 & 2409569629,675 & & 1,883 &, 096 \\
\hline jumlah nasabah & 787,018 & 812,429 &, 482 &, 969 &, 361 \\
\hline pendapatan &, 224 &, 285 &, 310 &, 788 &, 453 \\
\hline tingkat suku bunga & $-55470520,793$ & 93755781,371 &,- 283 &,- 592 &, 570 \\
\hline
\end{tabular}

Berdasarkan analisis data yang menggunakan perhitungan regresi sederhana dengan program Statistical for product and servise solution (SPSS) versi 22, maka didapatkan hasil sebagai berikut:

Tabel 4.5. Hasil Estimasi Regresi

a. Dependent Variable: penyaluran kredit

Maka persamaan sebagai berikut :

$$
\mathrm{Y}=4.538 .126 .865,36+787,018 \mathrm{X} 1+0,224 \times 2-55470520,793 \times 3+\mathrm{e}
$$

Persamaan regresi di atas dapat dijelaskan sebagai berikut:

Konstanta sebesar 4.538.126.865,36; artinya jika jumlah nasabah $\left(\mathrm{X}_{1}\right)$ Pendapatan $\left(\mathrm{X}_{2}\right)$ dan tingkat suku bunga nilainya adalah 0,096 maka Penyaluran kredit (Y') nilainya adalah Rp.4.538.126.865,36

Koefisien regresi variabel Jumlah nasabah $\left(\mathrm{X}_{1}\right)$ sebesar 787,018 artinya jika variabel independen lain nilainya tetap dan Jumlah nasabah (X1) mengalami kenaikan 1\%, maka harga saham (Y') akan mengalami penurunan sebesar Rp.74,482. Koefisien bernilai positif artinya terjadi hubungan positif antara jumlah 
nasabah dengan penyaluran kredit (Y), semakin naik jumlah nasabah maka semakin naik Penyaluran kredit .

Koefisien regresi variabel pendapatan $\left(\mathrm{X}_{2}\right)$ sebesar 0,224; artinya jika variabel independen lain nilainya tetap dan pendapatan mengalami kenaikan $1 \%$, maka penyaluran kredit (Y') akan mengalami peningkatan sebesar Rp.0,224. Koefisien bernilai positif artinya terjadi hubungan positif antara pendapatan dengan penyaluran kredit, semakin naik pendapatan maka semakin meningkat penyaluran kredit.

Koefisien regresi variabel tingkat suku bunga $\left(\mathrm{X}_{3}\right)$ sebesar- 55470520,793; artinya jika variabel independen lain nilainya tetap dantingkat suku bunga mengalami kenaikan 1\%, maka penyaluran kredit ( $\mathrm{Y}^{\prime}$ ) akan mengalami penurunan sebesar Rp55470520,793. Koefisien bernilai negatif artinya terjadi hubungan negatif antara tingkat suku bunga dengan penyaluran kredit, semakin turun tingkat suku bunga maka semakin turun penyaluran kredit. Nilai penyaluran kredit yang diprediksi (Y') dapat dilihat pada tabel Casewise Diagnostics (kolomPredicted Value). Sedangkan Residual (unstandardized residual) adalah selisih antara Penyaluran kredit dengan Predicted Value, dan Std. Residual (standardized residual) adalah nilai residual yang telah terstandarisasi (nilai semakin mendekati 0 maka model regresi semakin baik dalam melakukan prediksi, sebaliknya semakin menjauhi 0 atau lebih dari 1 atau -1 maka semakin tidak baik model regresi dalam melakukan prediksi).

\section{Analisis Koefesiensi Determinasi}

Uji koefisien Determinasi (R2), analisis untuk mengetahui seberapa besar sumbangan atau kontribusi variabel independen (Jumlah nasabah, pendapatan pegadaian dan tingkat suku bunga ) terhadap variabel dependen (penyaluran kredit). Besar koefisien determinasi (R2) didapat dari menguadratkan koefisien korelasi (r). Koefisien Determinasi dapat dilambangkan dengan (R2). Untuk menghitung pengaruh Jumlah nasabah, pendapatan pegadaian dan tingkat suku bunga terhadap penyaluran kredit, maka digunakan spss versi 22.

\section{Dasar keputusan uji korelasi berganda}

Pengambilan keputusan daam uji korelasi berganda dapat dengan membandingkan antara nilai probabilitas 0,05 dengan nilai probilitas sig $\mathrm{f}$ dengan dasar pengambilan 
keputusan sebagai berikut :

1. Jika nilai probabilitas 0,05 lebih kecil atau sama dengan nilai probabilitas sig F chame atau $(0,05<\operatorname{sig} \mathrm{F}$ change $)$, maka Ho diterima dan Ha ditolak, artinya tidak ada hubungan yg signifikanantara variabel $\mathrm{x}$ dengan y

2. Jika nilai probabilitas 0,05 lebih besar dari nilai probabilitas sig $\mathrm{F}$ change atau (0,05 > sig F change ), maka Ho ditolak dan Ha diterima, artinya ada hubungan yg signifikan antara variabel x dengan y

Tabel 4.6.Analisis Koefesien Determinasi

Model Summary

\begin{tabular}{|l|l|l|l|l|}
\hline Model & R & R Square & Adjusted R Square & Std. Error of the Estimate \\
\hline 1 &, $346^{\mathrm{a}}$ &, 120 &,- 211 & 75655243,039 \\
\hline
\end{tabular}

a. Predictors: (Constant), tingkat suku bunga, pendapatan, jumlah nasabah

b. Dependent Variable: penyaluran kredit

Berdasarkan tabel 4.6. model summary diketahui bahwa besarnya hubungan antara variabel X1 (Jumlah nasabah), Variabel X2 (Pendapatan pegadaian ) dan variabel X3 (tingkat suku bunga) terhadap variabel Y (Penyaluran kredit ) yang dihitung dengan koefesien korelasi sebesar 0,346 hal ini menunjukkan ada pengaruh yang signifikan antara variabel $\mathrm{X}$ dengan Variabel Y. Kontribusi atau sumbangangan secara simultan variabel Jumlah nasabah, pendapatan dan tingkat suku bunga terhadap penyaluran kredit sebesar 34,6 \% sedangkan 65,4\% ditentukan oleh variabel lain Untuk mengetahui tingkat signifikansi koefesien korelasi ganda diuji secara keseluruhan hipotesis yang diajukan dalam pembahasan inini adalah :

1. Ho : Jumlah nasabah, pendapatan pegadaian dan tingkat suku bunga tidak ada hubungan secara simulatan dan signifikansi terhadap penyaluran kredit, artinya Ho ditolak Ha : Jumlah nasabah, pendapatan pegadaian dan tingkat suku bunga ada hubungan secara simultan dan signifikan terhadap penyaluran kredit, $\mathrm{Ha}$ diterima

\section{Pengujian F Statistik ( Uji Simultan )}

Uji F digunakan untuk mengetahui apakah seluruh variable bebas yang diteliti secara bersama-sama atau simultan berpengaruh terhadap variable terikat.mencari $\mathrm{F}$ tabel yaitu : $\mathrm{F}$ tabel $=\mathrm{f}(\mathrm{k}, \mathrm{n}-\mathrm{k})=\mathrm{F}(3,8)$ jadi nilai $\mathrm{F}$ tabel sebesar 4,07 , dengan syarat diterimanya hipotesis dengan membandingkan nilai $t$ hitung dengan nilai $t$ 
tabel, apabila :

1. Jika nilai sig $<0,05$ atau $\mathrm{F}$ hitung $>\mathrm{F}$ tabel maka terdapat pengaruh variabel independen jumlah nasabah (X1), pendapatan pegadaian (X2) dan tingkat suku bunga (X3) secara simultan terhadap variabel dependent penyaluran kredit (Y)

2. Jika nilai sig $>0,05$ atau $\mathrm{F}$ hitung $<\mathrm{F}$ tabel maka tidak ada pengaruh variabel independent jumlah nasabah(X1), pendapatan pegadaian (X2) dan tingkat suku bunga (X3) secara simultan terhadap variabel dependent penyaluran kredit (Y)

Tabel 4.7. Hasil Uji F( Simultan )

ANOVA

\begin{tabular}{|c|c|c|c|c|c|}
\hline Model & Sum of Squares & $\mathrm{df}$ & Mean Square & $\mathrm{F}$ & Sig. \\
\hline $\begin{array}{ll}1 & \text { Regression } \\
& \text { Residual } \\
& \text { Total }\end{array}$ & $\begin{array}{l}6216007443082565,000 \\
45789726394142432,000 \\
52005733837225000,000\end{array}$ & $\mid \begin{array}{l}3 \\
8 \\
11\end{array}$ & $\begin{array}{l}2072002481027521,000 \\
5723715799267804,000\end{array}$ &, 362 &, $782^{b}$ \\
\hline
\end{tabular}

a. Dependent Variable: penyaluran kredit

b. Predictors: (Constant), tingkat suku bunga, pendapatan, jumlah nasabah

Perumusan Hipotesis :

H0 = Diduga Jumlah nasabah, pendapatan pegadaian dan tingkat suku bunga tidak berpengaruh secara simultan terhadap penyaluran kredit

H1 = Diduga julah nasabah, pendapatan pegadaian dan tingkat suku bunga secara simultan berpengaruh signifikan terhadap penyaluran kredit

Dari tabel 4.7 yang telah dijelaskan sebelumnya. terlihat bahwa hasil pengujian hipotesis secara simultan pengaruh jumlah nasabah, pendapatan dan tingkat suku bunga terhadap penyaluran kredit menunjukkan nilai $\mathrm{F}$ hitung sebesar 0,362 dengan taraf signifikansi 0,782. Taraf signifikansi tersebut lebih besar dari 0,05 dan nilai F hitung $(0,362)<$ nilai F- tabel $(4,07)$ yang berarti bahwa hipotesis H0 ditolak dan $\mathrm{H} 1$ diterima atau dengan kata lain variable jumlah nasabah, pendapatan dan tingkat suku bunga secara simultan tidak berpengaruh signifikan terhadap penyaluran kredit.

\section{Pengujian T Statistik (Uji Parsial )}

1) Uji t (Pengujian hipotesis secara parsial). Uji-t digunakan untuk mengetahui sejauh mana pengaruh parsial variabel bebas terhadap variabel terikat. 
Melalui uji - $\mathrm{t}$ dapat juga diketahui mengenai informasi tentang seberapa besar pengaruh variabel bebas terhadap laba. Mencari $\boldsymbol{t}$ tabel yaitu : t ( $\alpha / 2$; $\mathrm{n}-\mathrm{k}-1)$, $\mathrm{t}(0,025 ; 8)$, jadi nilai $\mathrm{t}$ tabel sebesar 2.306, dengan syarat diterimanya hipotesis dengan membandingkan nilai t hitung dengan nilai $t$ tabel , apabila Jika nilai sig $<0,05$ atau t hitung $>\mathrm{T}$ tabelmaka terdapat pengaruh variabel independent jumlah nasabah(X1), pendapatan pegadaian (X2) dan tingkat suku bunga (X3) terhadap variabel dependent penyaluran kredit (Y)

2) Jika nilai sig $>0,05$ atau t hitung $<\mathrm{T}$ table maka tidak terdapat pengaruh variabel independent jumlah nasabah(X1), pendapatan pegadaian (X2) dan tingkat suku bunga (X3) terhadap variabel dependent penyaluran $\operatorname{kredit}(\mathrm{Y})$

Tabel 4.8. Hasil Uji T (Uji Parsial )

\begin{tabular}{|c|c|c|c|c|c|}
\hline \multicolumn{6}{|c|}{ Coefficients $^{\mathrm{a}}$} \\
\hline \multirow[b]{2}{*}{ Model } & \multicolumn{2}{|c|}{ Unstandardized Coefficients } & \begin{tabular}{|l|l} 
Standardized \\
Coefficients
\end{tabular} & \multirow[b]{2}{*}{ t } & \multirow[b]{2}{*}{ Sig. } \\
\hline & $\mathrm{B}$ & Std. Error & Beta & & \\
\hline $1 \quad$ (Constant) & 4538126865,365 & 2409569629,675 & & 1,883 &, 096 \\
\hline jumlah nasabah & 787,018 & 812,429 &, 482 &, 969 &, 361 \\
\hline pendapatan &, 224 &, 285 &, 310 &, 788 &, 453 \\
\hline tingkat suku bunga & $-55470520,793$ & 93755781,371 &,- 283 &,- 592 &, 570 \\
\hline
\end{tabular}

a. Dependent Variable: penyaluran kredit

\section{Uji Hipotesis 1 (H1)}

- H0 : Jumlah nasabah, secara parsial tidak berpengaruh signifikan terhadap penyaluran kredit

- H1 : Jumlah nasabah, secara parsial berpengaruh berpengaruh signifikan terhadap penyaluran kredit.

Dari tabel 4.8. di atas terlihat bahwa hasil pengujian hipotesis tentang Jumlah nasabah menunjukkan nilai t hitung sebesar 0,969 dengan taraf signifikansi 0,361 Taraf signifikansi tersebut lebih besar dari 0,05 dan nilai t hitung $0,969<$ dari nilai t tabel (2,306) yang berarti bahwa hipotesis H1 ditolak dan Ho diterima, atau dengan kata lain variable Jumlah nasabah secara parsial tidak berpengaruh signifikan terhadap penyaluran kredit

\section{Uji Hipotesis 2 (H2)}


- H0 : Pendapatan secara parsial berpengaruh signifikan terhadap penyaluran kredit

- H2 : pendapatan secara parsial tidak berpengaruh signifikan terhadap penyaluran kredit

Dari tabel 4.8. di atas terlihat bahwa hasil pengujian hipotesis tentang pendapatan pegadaian menunjukkan nilai t hitung sebesar 0.788 dengan taraf signifikansi 0,453 . Taraf signifikansi tersebut lebih besar dari 0,05 dan nilai t hitung $(0,788)<$ nilai $t$ tabel $(2,306)$ yang berarti bahwa hipotesis $\mathrm{H} 0$ diterima dan $\mathrm{H} 2$ ditolak, atau dengan kata lain variable pendapatan pegadaian secara parsial tidak berpengaruh signifikan terhadap penyaluran kredit.

\section{Uji Hipotesis 3 (H3)}

- H0 :tingkat suku bunga secara parsial berpengaruh signifikan terhadap penyaluran kredit .

- H3 :tingkat suku bunga secara parsial tidak berpengaruh secara signifikan terhadap penyaluran kredit .

Dari tabel 4.8. di atas terlihat bahwa hasil pengujian hipotesis tentang tingkat suku bunga menunjukkan nilai t hitung sebesar 0,592 dengan taraf signifikansi 0,570 . Taraf signifikansi tersebut lebih besar dari 0,05 dan nilai t hitung 0,592 < nilai t tabel $(2,306)$ yang berarti bahwa hipotesis H0 diterima dan H3 ditolak, atau dengan kata lain variable pendapatan pegadaian secara parsial tidak berpengaruh signifikan terhadap penyaluran kredit.

\section{Analisa Uji Asumsi Klasik}

\section{Uji multikoliniaritas}

Uji multikolinearitas adalah uji yang dilakukan untuk memastikan apakah di dalam sebuah model regresi ada interkorelasi atau kolinearitas antar variabel bebas. Interkorelasi adalah hubungan yang linear atau hubungan yang kuat antara satu variabel bebas atau variabel prediktor dengan variabel prediktor lainnya di dalam sebuah model regresi. Interkorelasi itu dapat dilihat dengan nilai koefisien korelasi antara variabel bebas, nilai VIF dan Tolerance, nilai Eigenvalue dan Condition Index, serta nilai standar error koefisien beta atau koefisien regresi 
parsial. Selanjutnya pastikan nilai rentang upper dan lowebound confidence inteval, apakah lebar atau sempit. Berikut hasilnya :

Tabel 4.9. Uji Multikolniaritas

\begin{tabular}{|c|c|c|c|c|c|c|c|}
\hline \multicolumn{8}{|c|}{ Coefficients $^{\mathrm{a}}$} \\
\hline \multirow[b]{2}{*}{ Model } & \multicolumn{2}{|c|}{ Unstandardized Coefficients } & \multirow{2}{*}{$\begin{array}{l}\text { Standardized } \\
\text { Coefficients } \\
\text { Beta }\end{array}$} & \multirow[b]{2}{*}{$\mathrm{t}$} & \multirow[b]{2}{*}{ Sig. } & \multicolumn{2}{|c|}{$\begin{array}{l}\text { Collinearity } \\
\text { Statistics } \\
\end{array}$} \\
\hline & $\mathrm{B}$ & Std. Error & & & & Tolerance & VIF \\
\hline $1 \quad$ (Constant) & 4127404425,606 & 2525183206,458 & & 1,634 & 141 & & \\
\hline jumlah nasabah & 149,091 & 2713,432 & 022 & 055 & 958 &, 777 & 1,287 \\
\hline pendapatan &, 076 &, 271 & 105 &, 280 & ,786 & 875 & 1,142 \\
\hline $\begin{array}{l}\text { tingkat suku } \\
\text { bunga }\end{array}$ & 7884497,037 & 73817228,119 & 040 &, 107 & 918 & 868 & 1,153 \\
\hline
\end{tabular}

a. Dependent Variable: penyaluran kredit

VIF dan Tolerance Uji Multikolinearitas Perhatikan pada tabel coeffecient diatas, bahwa nilai rentangnya sempit, yaitu pada $\mathrm{X} 1=0,777$ sampai dengan 1,287, $\mathrm{X} 3=0,868$ sampai dengan $1,153, \mathrm{X} 2=0,875$ sampai dengan 1,142 nilai multikolinearitas tidak terdeteksi.

\section{Deteksi Multikolinearitas dengan nilai VIF dan Tolerance dalam regresi.}

Pada tabel yang sama sebagai hasil uji regresi linear, perhatikan nilai VIF dan Tolerance. Variabel X1 dan X3 adalah indikasi kuat yang sering dipakai oleh para peneliti untuk menyimpul fenomena terjadinya interkorelasi variabel bebas. Jika nilai VIF kurang dari 10 dan atau nilai tolerance lebih dari 0,01 maka dapat disimpulkan dengan tegas bahwa tidapat masalah multikolinearitas. Dan sebaliknya maka dapat disimpulkan dengan tegas pula bahwa multikolineraritas telah terjadi dalam model. Selanjutnya yang terakhir d idalam output proses yang sudah kita lakukan, kita perhatikan nilai collnearity diagnostics seperti dibawah ini :

Tabel 4.10 Collinearity Diagnostics ${ }^{\mathrm{a}}$

\begin{tabular}{|c|c|c|c|c|c|c|c|}
\hline \multirow[b]{2}{*}{ Model } & \multirow[b]{2}{*}{ Dimension } & \multirow[b]{2}{*}{ Eigenvalue } & \multirow[b]{2}{*}{$\begin{array}{l}\text { Condition } \\
\text { Index }\end{array}$} & \multicolumn{4}{|c|}{ Variance Proportions } \\
\hline & & & & (Constant) & $\begin{array}{l}\text { jumlah } \\
\text { nasabah }\end{array}$ & pendapatan & $\begin{array}{ll}\text { tingkat suku } \\
\text { bunga }\end{array}$ \\
\hline 1 & 1 & 4,000 & 1,000 & 00 & 00 & 00 & 00 \\
\hline & 2 & 000 & 161,120 &, 07 & ,97 &, 07 &, 04 \\
\hline & 3 &, 000 & 178,388 &, 00 &, 00 &, 50 &, 52 \\
\hline & 4 & $5,543 \mathrm{E}-5$ & 268,620 &, 93 &, 03 &, 44 & 0,44 \\
\hline
\end{tabular}

a. Dependent Variable: penyaluran kredit

\section{Collinearity Diagnostics SPSS}

Deteksi Multikolinearitas dengan Eigenvalue dan condition Index. 
Pada tabel 4.10 Collinearity Diagnostics diatas hasil uji regresi linear perhatikan nilai eigenvalue dan condition index. Jika eigenvalue lebih dari 0,01 dan atau cndition index kurang dari 30, maka dapat disimpulkan bahwa gejala multikolinearitas tidak terjadi di dalam model regresi. Nilai eigenvalue 5,543>0,01 walaupun collenearity diagnostics 268,620 dimana lebih dari 30 .

\section{Uji Heterokedastisitas}

Uji heteroskedastisitas digunakan untuk mengetahui ada atau tidaknya penyimpangan asumsi klasik heteroskedastisitas yaitu adanya ketidaksamaan varian dari residual untuk semua pengamatan pada model regresi. Prasyarat yang harus terpenuhi dalam model regresi adalah tidak adanya gejala heteroskedastisitas. Ada beberapa metode pengujian yang bisa digunakan diantaranya yaitu Uji Park, Uji Glesjer, Melihat pola grafik regresi, dan uji koefisien korelasi Spearman.

Tabel 4.11. Uji Heterokedastisitas Coefficients $^{\mathrm{a}}$

\begin{tabular}{|c|c|c|c|c|c|c|c|}
\hline \multirow[b]{2}{*}{ Model } & \multicolumn{2}{|c|}{ Unstandardized Coefficients } & \multirow{2}{*}{\begin{tabular}{|l} 
Standardized \\
Coefficients \\
Beta
\end{tabular}} & & \multirow[b]{2}{*}{ Sig. } & \multicolumn{2}{|c|}{$\begin{array}{l}\text { Collinearity } \\
\text { Statistics }\end{array}$} \\
\hline & $\mathrm{B}$ & Std. Error & & & & Tolerance & VIF \\
\hline $1 \quad$ (Constant) & 4127404425,606 & 2525183206,458 & & 1,634 & 141 & & \\
\hline jumlah nasabah & 149,091 & 2713,432 &, 022 & 055 & ,958 & ,777 & 1,287 \\
\hline pendapatan & 076 &, 271 & 105 & 280 & ,786 & 875 & 1,142 \\
\hline $\begin{array}{l}\text { tingkat suku } \\
\text { bunga }\end{array}$ & 7884497,037 & 73817228,119 &, 040 & 107 &, 918 & 868 & 1,153 \\
\hline
\end{tabular}

a. Dependent Variable: penyaluran kredit

Berdasarkan tabel 4.11. berdasarkan output diatas diketahui nilai signifikasi variabel jumlah nasabah (X1) sebesar 0,958 lebih besar dari 0,05 artinya tidak terjadi heteroskedastisitas pada variabel jumlah nasabah (X1), sementara itu diketahui nilai signifikasi variabel X2 ( pendapatan) sebesar 0,786 lebih besar dari 0,05 dan nilai signifikasi variabel X3 (tingkat suku bunga ) sebesar 0,918 lebih besar dari 0,05 tidak terjadi heteroskedastisitas

\section{Uji Autokorelasi}

Uji Autokorelasi digunakan untuk mengetahui adanya korelasi yang terjadi antara residual pada satu pengamatan dengan pengamatan lain model regresi. Model regresi diharuskan tidak adanya autokorelasi. Pengujian autokorelasi dilihat dari output Durbin Watson (DW) dengan ketentuan sebagai berikut :

1. $\mathrm{d}<\mathrm{dl}$ atau $\mathrm{d}>4-\mathrm{dl}$, maka terjadi autokorelasi 
2. $\quad \mathrm{du}<\mathrm{d}<4$-du, maka tidak terjadi autokorelasi

3. $\mathrm{dl}<\mathrm{d}<\mathrm{dl}$ atau $4-\mathrm{du}<\mathrm{d}<4 \mathrm{dl}$, maka tidak ada kesimpulan yang berati.

Tabel 4.11. Hasil Uji Autokorelasi

\begin{tabular}{|l|r|r|r|r|r|}
\hline Model & \multicolumn{1}{|c|}{ Model Summary $^{\mathbf{b}}$} \\
\hline 1 &, $129^{2}$ & R Square & Adjusted R Square & Std. Error of the Estimate & Durbin-Watson \\
\hline &, 017 &,- 352 & 79954435,58009 & 1,525 \\
\hline
\end{tabular}

a. Predictors: (Constant), tingkat suku bunga, pendapatan, jumlah nasabah

b. Dependent Variable: penyaluran kredit

Diketahui $\mathrm{n}=12, \mathrm{k}=3, \mathrm{DW}=1,525, \mathrm{dl}=0,6577$ (lihat tabel Durbin Watson), $\mathrm{du}=1,8640$ ( lihat tabel DW), $\alpha=5 \%$

Berdasarkan tabel 4.11. hasil uji autokorelasi di atas mengahasilkan nilai DurbinWatson sebesar 1,525. Pada (tabel DW) maka diketahui dl sebesar 0,657 dan du sebesar 1,864, nsebesar 12 , Variabel independen $(\mathrm{k})=3$ dan tarip signifikansi 5\%, maka dari hasil tersebut diatas $\mathrm{dl}<\mathrm{dw}<\mathrm{du}$ hasilnya tidak terjadi autokorelasi

\section{Uji Normalitas}

Uji Normalitas berguna untuk menentukan data yang telah dikumpulkan berdistribusi normal atau diambil dari populasi normal. Metode klasik dalam pengujian normalitas suatu data tidak begitu rumit. Berdasarkan pengalaman empiris beberapa pakar statistik, data yang banyaknya lebih dari 30 angka (n > 30), maka sudah dapat diasumsikan berdistribusi normal. Biasa dikatakan sebagai sampel besar. Namun untuk memberikan kepastian, data yang dimiliki berdistribusi normal atau tidak, sebaiknya digunakan uji normalitas. Karena belum tentu data yang lebih dari 30 bisa dipastikan berdistribusi normal, demikian sebaliknya data yang banyaknya kurang dari 30 belum tentu tidak berdistribusi normal, untuk itu perlu suatu pembuktian. uji statistik normalitas yang dapat digunakan diantaranya Chi-Square, Kolmogorov Smirnov, Lilliefors, Shapiro Wilk, Jarque Bera. 
Tabel 4.12. Uji Normalitas

One-Sample Kolmogorov-Smirnov Test

\begin{tabular}{|c|c|c|c|c|}
\hline & & $\begin{array}{l}\text { jumlah } \\
\text { nasabah }\end{array}$ & pendapatan & $\begin{array}{l}\text { tingkat suku } \\
\text { bunga }\end{array}$ \\
\hline $\mathrm{N}$ & & 12 & 12 & 12 \\
\hline \multirow{2}{*}{ Normal Parameters ${ }^{\mathrm{a}, \mathrm{b}}$} & Mean & 598635,58 & 7480509794,33 & 27,65 \\
\hline & Std. Deviation & 10080,477 & 94900820,959 & ,351 \\
\hline \multirow[t]{3}{*}{ Most Extreme Differences } & Absolute &, 162 &, 356 &, 168 \\
\hline & Positive &, 154 & ,266 &, 168 \\
\hline & Negative &,- 162 &,- 356 &,- 105 \\
\hline Test Statistic & & ,162 & ,356 & , 168 \\
\hline Asymp. Sig. (2-tailed) & & $200^{\mathrm{c}, \mathrm{d}}$ & $000^{\circ}$ & $200^{\mathrm{c}, \mathrm{d}}$ \\
\hline
\end{tabular}

a. Test distribution is Normal.

b. Calculated from data.

c. Lilliefors Significance Correction.

$\mathrm{d}$. This is a lower bound of the true significance.

Berdasarkan hasil pengujian dengan spss didapatkan nilai signifikansi dari masing-masing variabel adalah sebagai berikut :

- Variabel jumlah nasabah (X1) nilai sig sebesar 0,200>0,05. Maka Kesimpulan Ho ditolak dan Ha diterima , artinya distribusi data tersebut normal

- Variabel pendapatan (X2) nilai sig sebesar 0,000 < 0,05. Maka Kesimpulan Ho diterima dan Ha ditolak , artinya distribusi data tersebut tidak normal

- Variabel tingkat suku bunga (X3) nilai sig sebesar 0,200>0,05. Maka Kesimpulan Ho ditolak dan Ha diterima , artinya distribusi data tersebut normal

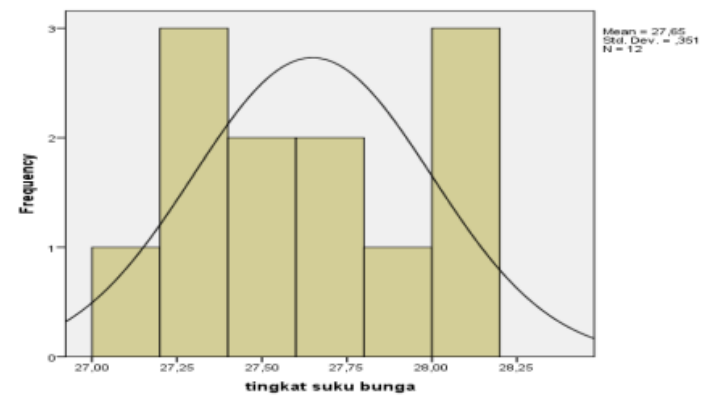

\section{Uji Korelasi Parsial}

Gambar 3 Uji Normalitas

Sebagaimana halnya analisis korelasi bivariat, korelasi parsial juga berfungsi untuk mengetahui hubungan 2 variabel. namun pada analisis ini, agak sedikit berbeda dengan korelasi bivariate karena pada analisis ini terdapat suatu variabel yang menjadi kontrol pada 2 variabel yang akan diketahui hubungannya 
Tabel 4.13. Hasil Uji Korelasi Parsial

\begin{tabular}{|c|c|c|c|c|c|c|}
\hline \multicolumn{7}{|c|}{ Correlations } \\
\hline \multicolumn{3}{|c|}{ Control Variables } & $\begin{array}{l}\text { jumlah } \\
\text { nasabah }\end{array}$ & pendapatan & $\begin{array}{l}\text { tingkat suku } \\
\text { bunga }\end{array}$ & $\begin{array}{l}\text { penyaluran } \\
\text { kredit }\end{array}$ \\
\hline \multirow[t]{12}{*}{- none $^{\mathrm{a}}$} & \multirow[t]{3}{*}{ jumlah nasabah } & Correlation & 1,000 &,- 310 & ,624 & ,209 \\
\hline & & Significance (2-tailed) & &, 327 &, 030 &, 514 \\
\hline & & df & 0 & 10 & 10 & 10 \\
\hline & \multirow[t]{3}{*}{ pendapatan } & Correlation &,- 310 & 1,000 &, 147 & ,119 \\
\hline & & Significance (2-tailed) &, 327 & & ,648 & ,714 \\
\hline & & df & 10 & 0 & 10 & 10 \\
\hline & \multirow[t]{3}{*}{ tingkat suku bunga } & Correlation & ,624 & 147 & 1,000 & ,064 \\
\hline & & Significance (2-tailed) & ,030 & 648 & & 844 \\
\hline & & df & 10 & 10 & 0 & 10 \\
\hline & \multirow[t]{3}{*}{ penyaluran kredit } & Correlation & ,209 & ,119 & ,064 & 1,000 \\
\hline & & Significance (2-tailed) & ,514 & ,714 & 844 & \\
\hline & & df & 10 & 10 & 10 & 0 \\
\hline \multirow{9}{*}{$\begin{array}{l}\text { penyaluran } \\
\text { kredit }\end{array}$} & \multirow{3}{*}{ jumlah nasabah } & Correlation & 1,000 &,- 345 & ,626 & \\
\hline & & Significance (2-tailed) & & 299 & ,039 & \\
\hline & & $\mathrm{df}$ & 0 & 9 & 9 & \\
\hline & \multirow[t]{3}{*}{ pendapatan } & Correlation &,- 345 & 1,000 & ,141 & \\
\hline & & Significance (2-tailed) & ,299 & & ,679 & \\
\hline & & $\mathrm{df}$ & 9 & 0 & 9 & \\
\hline & \multirow[t]{3}{*}{ tingkat suku bunga } & Correlation & 626 & ,141 & 1,000 & \\
\hline & & Significance (2-tailed) & 039 & 679 & & \\
\hline & & df & & & 0 & \\
\hline
\end{tabular}

a. Cells contain zero-order (Pearson) correlations.

1. Output terdiri dari 2 bagian yaitu, bagian pertama menunjukkan korelasi dengan variabel Penyaluran kredit diikut sertakan. Tampak bahwa koefisien korelasi antara Pendapatan dan Jumlah nasabah -0,310 Dan nilai signifikansi 0,327 yang berarti pendapatan dan jumlah nasabah mempunyai korelasi ($0,310<0.05)$

2. Output terdiri dari 2 bagian yaitu, bagian pertama menunjukkan korelasi dengan variabel Penyaluran kredit diikut sertakan. Tampak bahwa koefisien korelasi antara tingkat suku bunga dan Jumlah nasabah 0,624 Dan nilaisignifikansi 0,030 yang berarti tingkat suku bunga dan jumlah nasabah tidak mempunyai korelasi $(0,624>0.05)$.

3. Pada bagian kedua, variabel penyaluran kredit tidak diikut sertakan. Tampak bahwa koefsien korelasi antara Pendapatan dan Jumlah nasabah menjadi 0,345 (turun dari nilai sebelumnya). Dan nilai signifikansi menjadi 0,299, yang berarti pendapatan dan Jumlah nasabah menjadi ada korelasi ($0,345<0.05)$. Pada bagian kedua, variabel penyaluran kredit tidak diikut sertakan. Tampak bahwa koefsien korelasi antara tingkat suku bunga dan 
Jumlah nasabah menjadi 0,626 (naik dari nilai sebelumnya). Dan nilai signifikansi menjadi 0,039, yang berarti pendapatan dan Jumlah nasabah menjadi ada korelasi $(0,626>0.05)$. tidak mempunyai korelasi. Hal ini berarti penyaluran kredit cukup penting untuk mendorong pendapatan pegadaian dan mendapatkan jumlah nasabah yang cukup besar.

\section{Interprestasi}

Analisa regresi dengan jumlah variabel indenpenden lebih dari satu dengan satu variabel dependen. Ada tambahan asumsi yang harus dipenuhi, yaitu ; tidak boleh ada hubungan antar variabel-variabel independennya (uji multikolinearitas).

Untuk menentukan apakah data anda berdistribusi normal menggunakan shapiro wilk, maka pada SPSS cukup anda lihat nilai Sig. pada kolom Shapiro-Wilk. Nilai sig itu berarti signifikansi atau boleh disebut $\mathrm{p}$ value atau nilai probabilitas. Pada contoh di atas nilainya sebesar 0,96 lebih dari 0,05, maka dapat dikatakan data berdistribusi Normal atau yang berarti menerima H0.

Untuk pengambilan keputusan statistik, dapat digunakan 2 cara:

Koefisien Korelasi dibandingkan dengan nilai $r$ tabel (korelasi tabel),

1. Apabila koefesien korelasi > $\mathrm{r}$ tabel, maka ada hubungan yang signifikan (Ha diterima).

2. Apabila koefesien $<\mathrm{r}$ tabel, maka tidak ada hubungan yang signifikan (Ho diterima)

3. Melihat Signifikan

a. Apabila nilai sig < 0,05 maka ada hubungan yang signifikan (Ha diterima)

b. Apabila nilai sig >0,05 maka tidak ada hubungan yang signifikan (Ho diterima)

c. Arah Hubungan: Dilihat dari tanda koefesien: tanda (-) berati apabila variabel $\mathrm{x}$ tinggi maka variabel y rendah.

Tanda $(+)$ berati apabila variabel $\mathrm{x}$ tinggi maka variabel y juga tinggi Untuk menentukan korelasi ganda, Melihat nilai R semakin mendekati 1 maka hubungan semakin kuat guna memperkaya analisis sebelum dianalisis korelasi ganda dapat juga ditambahkan analisis korelasi pada masing-masing variabel independen dengan variabel dependen (caranya sama dengan analisis korelasi pearson. 


\section{Kesimpulan}

Berdasarkan urain-uraian yang telah penulis paparkan terhadap data penelitian yang telah terkumpul kemudian diolah mengenai pengaruh jumlah nasabah, pendapatan dan tingkat suku bunga terhadap penyaluran Kredit PT Pegadaian Cabang Kabupaten periode 2013-2017, maka penulis dapat menarik kesimpulan antara lain, sebagai berikut:.

a. Uji Regresi linear berganda skor tes jumlah nasabah thitung =0,96 dengan probalitas $0,361<0,5$, artinya ada pengaruh yang sgnifikan. Untuk variabel pendapatan $\mathrm{t}$ hitung 0,788 dengan probalitas $0,45<0,5$, artinya ada pengaruh yang signifikan dan untuk variabel tingkat suku bunga thitung =0,592 dengan probalitas $0,570>$, artinya tidak ada pengaruh signifikan.

b. Uji F (simultan) pengaruh jumlah nasabah, pendapatan dan tingkat suku bunga terhadap penyaluran kredit menunjukkan nilai $\mathrm{F}$ hitung sebesar 0,362 dengan taraf signifikansi 0,782. Taraf signifikansi tersebut lebih besar dari 0,05 dan nilai F hitung $(0,362)<$ nilai F- tabel $(4,07)$ yang berarti bahwa hipotesis $\mathrm{H} 0$ ditolak dan $\mathrm{H} 1$ diterima atau dengan kata lain variable jumlah nasabah, pendapatan dan tingkat suku bunga secara simultan tidak berpengaruh signifikan terhadap penyaluran kredit.

c. hasil pengujian secara parsial (Uji T) tentang Jumlah nasabah menunjukkan nilai $\mathrm{t}$ hitung sebesar 0,969 dengan taraf signifikansi 0,361 Taraf signifikansi tersebut lebih besar dari 0,05 dan nilai t hitung $0,969<$ dari nilai t tabel $(2,306)$ yang berarti bahwa hipotesis H1 ditolak dan Ho diterima, atau dengan kata lain variable Jumlah nasabah secara parsial tidak berpengaruh signifikan terhadap penyaluran kredit

\section{Daftar Pustaka}

Agus, Sartono. 1997. Manajemen keuangan, BPFEE, Yogyakarta

Annual Report PT Pegadaian (Persero), 2004 s/d 2013, dikutip tanggal 12 september 2014

Bambang Riyanto, 1997, Dasar-dasar Pembelanjaan Perusahaan Edisi Keempat, BPEE : Yogyakarta. 
Griffin dan Ronal d J. Ebert, "Bisnis”, buku satu, Edisi ke -4, Jakarta, 1996

Harianto dan Sudomo, 1998, Perangkat dan Teknik Analisis Investasi di Pasar Modal Indonesia, edisi pertama, BT Bursa Efek Jakarta, Jakarta

Kasmir. (2010). Pengantar Manajemen Keuangan. Jakarta : Kencana Prenada Media Group.

Kasmir, 2005. Bank dan Lembaga Keuangan Lainnya, Edisi 6, PT. Raja Grafindo Persada, Jakarta.

Krisnawati, Arina. 2011. Analisa Beberapa Faktor Yang Mempengaruhi

Penyaluran Kredit bank Umum di Indonesia. Terpublikasi

Sitio, Arifi. 2001. Koperasi : Teori dan praktik. Jakarta : Erlangga.

Lumbatorum, 2001. Dasar-dasar akuntansi keuangan, Jakarta : Salemba 4

Muhammad, Ali. 2003, Penelitian Pendidikan. Pustaka Aman : Jakarta

Muhammad dan Hadi, 2003: 17 , Perusahaan Umum Pegadaian

Martono, Bank dan Lembaga Keuangan Lian, Cetakan ke empat, Yogyakarta: Ekonosia, 2010

Mabruroh. (2004). Manfaat Pengaruh Rasio Keuangan dalam Analisis Kinerja Keuangan PerbankanVol.8,No.1.

Pandia, Frianto, Lembaga Keuangan, Jakarta: Rineka Cipta, 2005

Pandia, dkk. Lembaga Keuangan, Jakarta : PT. Rineka Cipta, 2004.

Rais, Sasli, Pegadaian Syariah: Konsep dan Sistem Operasional, Jakarta: UI Press, 2006

Regar, Moenaf. 1993. Mengenal Profesi Akuntansi. Erlangga : Jakarta

Susilo \& Santoso , A. Totok, Budi. 2000. Bank Lembaga Keuangan Lain. Jakarta: Salemba Empat 